\title{
Damage to Salamandra infraimmaculata Populations by Human Activity in Creating Water Pits Is a Death Trap in Semi-Arid Habitats
}

\author{
Gad Degani1,2*, Udi Grosman², Tali Goldberg1,2, Nadav Hanegbi ${ }^{2}$ \\ ${ }^{1}$ MIGAL-Galilee Research Institute, Kiryat Shmona, Israel \\ ${ }^{2}$ Tel-Hai Academic College, Upper Galilee, Israel \\ Email: *gad@migal.org.il
}

How to cite this paper: Degani, G., Grosman, U., Goldberg, T. and Hanegbi, N. (2019) Damage to Salamandra infraimmaculata Populations by Human Activity in Creating Water Pits Is a Death Trap in Semi-Arid Habitats. Open Journal of Animal Sciences, 9, 23-34.

https://doi.org/10.4236/ojas.2019.91003

Received: August 31, 2018

Accepted: December 17, 2018

Published: December 20, 2018

Copyright $\odot 2019$ by authors and Scientific Research Publishing Inc. This work is licensed under the Creative Commons Attribution International License (CC BY 4.0).

http://creativecommons.org/licenses/by/4.0/

(c) (i) Open Access

\begin{abstract}
The different breeding sites of Salamandra infraimmaculata on the southern border of its distribution were examined and mapped in order to estimate the damage caused by water holes that could represent death traps for salamanders in xeric habitats. Among the various types of breeding sites (springs, streams, water holes, winter pools and reservoirs), the larvae of salamanders were detected in high numbers in springs and streams (503) and water holes (48), and in relatively low numbers in winter pools. Two water holes were examined in detail to estimate the damage caused to $S$. infraimmaculata where breeding places are limited. During the winter, both males and females enter a water hole for breeding. The percentage of males in and around the water hole was $42 \%$ and that of females $29 \%$. After the salamanders' oviposition in the water, they try to return to terrestrial habitats, but are unable to do so and lose weight and die. The body mass index (BMI) of salamanders decreases from winter (December) after they move to the water hole to spring (April), when they are found in the water hole. The estimation of potential damage is about 300 mature salamanders annually.
\end{abstract}

\section{Keywords}

Amphibia, Body Mass, Israel, Migration, Reproduction Cycle, Salamandra

\section{Introduction}

The genus Salamandra is distributed throughout Europe, northern Africa and the Near East. Many local populations have adapted to different climates in various 
habitats, but the status of species and subspecies of these populations is still a matter of dispute. Based on a mitochondrial DNA analysis, Steinfartz et al. [1] proposed the taxonomy and distribution of the Salamandra species in Europe and in Mediterranean countries. A phylogenetic analysis of the sequences suggests that six major monophyletic groups exist ( $S$. salamandra, $S$. algira, $S$. infraimmaculata, $S$. corsica, $S$. atra and $S$. lanzai) that combine together more than 14 subspecies [2]. Based on the Salamandra species distribution, S. algira, $S$. infraimmaculata and $S$. corsica are apparently found at the southern border of their distribution and are exposed to semi-arid conditions [3] [4].

Many studies have been carried out on genetic variation, not only among the species of Salamandra, but also among different populations in the same species, in order to understand the adaptation to different ecological conditions. Salamandra infraimmaculata is present in the southeastern and eastern parts of Anatolia, Turkey, northwestern Iran, northern Iraq, Lebanon and northern Israel [1]. Many aspects of $S$. infraimmaculata, some of which have been described in detail, have been studied over the past 40 years on the southern border of its distribution [3] [4].

This situation is very interesting in semi-arid habitats where strong effects of the habitats were found on genetic variation, as was seen in $\mathcal{S}$. algira [5] and $S$. infraimmaculata [3] [4]. It seems that $S$. infraimmaculata has been studied in more detail not only regarding genetic divergence [6]-[17], but also in terms of other biological and ecological aspects [2] [3] [4].

Although there are many aspects of $S$. infraimmaculata adaptation to dry conditions in semi-arid habitats [2] [3] [4], relatively limited studies have been carried out on the effect of breeding places on adaptation to semi-arid habitats in $S$. infraimmaculata. Breeding places where larvae development and complete metamorphosis take place have been studied quite extensively, and are described in detail on the southern border of $\mathcal{S}$. infraimmaculata distribution [2] [10] [18]-[26]. Relatively less information has been provided on metamorphosis and mature salamanders [27] [28] [29].

Two different activity patterns of metamorphosis in $S$. infraimmaculata were described: local year-round activity [23]; and migration to breeding places located at relatively long distances [27]. During the long migration to breeding places, the salamanders move to the same breeding places [23] [31] [32] or to new breeding places in the same area [27].

While seeking new breeding places in semi-arid habitats where many human-made water bodies suitable for $S$. infraimmaculata larvae development and complete metamorphosis are located, mature salamanders and metamorphosed juveniles are unable to move back to terrestrial habitats, and later on, all the salamanders die [32] [33].

S. infraimmaculata are facing foreseeable danger in semi-arid habitats where water bodies are limited and many human-made pits represent traps for salamanders. Estimations of damage to salamander populations are very important for nature conservation. 
In the present study, the breeding places of $S$. infraimmaculata are evaluated and described, as well as the potential damage of pits that might represent a trap for mature salamanders.

\section{Materials and Methods}

\section{Study Area}

The distribution of breeding places of $S$. infraimmaculata in northern Israel based on maps and various studies carried out over the past 40 years is presented in Figure 1. The breeding places were divided into four categories: ponds, which is a relatively large water body where water is available all-year-round or for more than half a year; water pools, which is a relatively small body where water is available for several months during the winter; springs, in which water coming from the ground is available all-year-round; and water holes, many of which are human-made wells for collecting water.

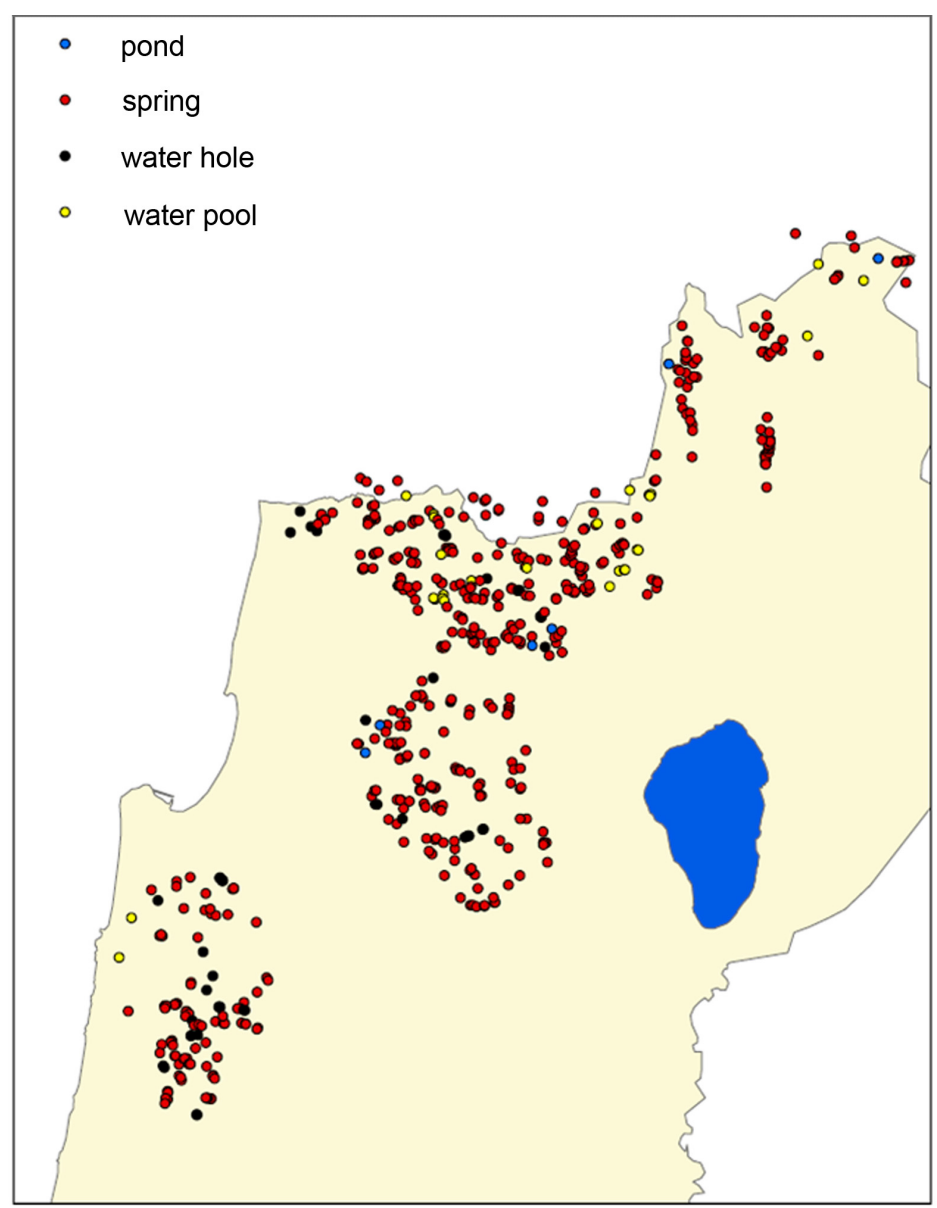

Figure 1. The map of water bodies of potential breeding sites of $S$. infraimmaculata according to the maps published by the government of Israel during the years 1941 to 2018 in the area of distribution of this species in Israel. Blue represents winter reservoirs, red represents springs and streams, black represents water holes and yellow represents winter pools. The source of the map of water bodies of potential breeding sites was provided by the Tel-Hai Map Archive. 
The study was carried out over eight consecutive years (2005-2014) in xeric habitats, including all habitats of $S$. infraimmaculata in Mount Carmel, the eastern, upper and northern Galilee, covering an area of approximately $1400 \mathrm{~km}^{2}$ in northern Israel, as described previously by Degani and Goldberg [32], and Degani and Kaplan [10]. The habitats examined in this area were existing or potential breeding places of $S$. infraimmaculata (in the area of distribution of this $S$. infraimmaculata) where salamanders can enter but cannot exit. We focused on breeding places of rock pool holes, wells and swimming pools in the area of $S$. infraimmaculata breeds (Figure 2) [26] [32] [34]. We also examined potential breeding places, as well as information published in maps or on the Internet (Figure 1). Two breeding places were selected for studying both larvae and mature salamanders in detail:

1) Shazur Mountain, at coordinates $181.4 / 262.5$ on the Israel topographical grid, an elevation of $800 \mathrm{~m}$ above sea level [33]. Two breeding places of $S$. infraimmaculata were discovered very close to this area $(200 \mathrm{~m}$ distance between
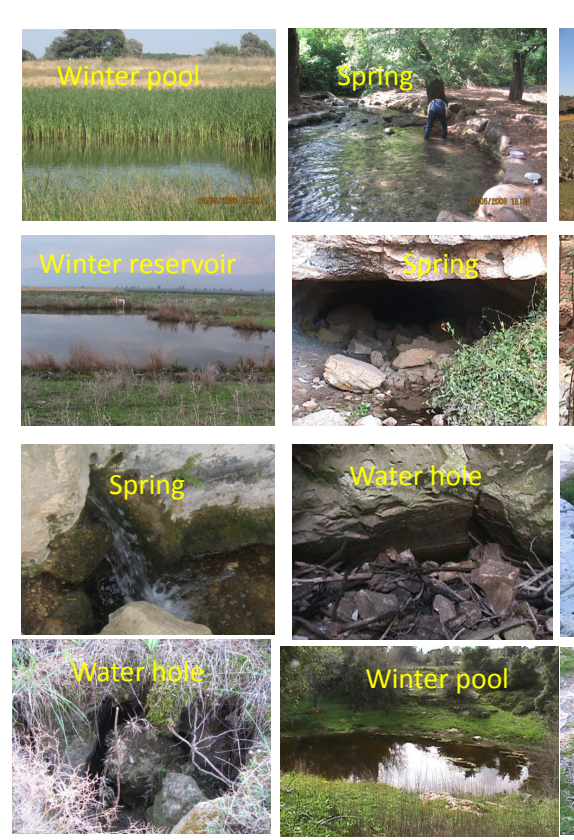

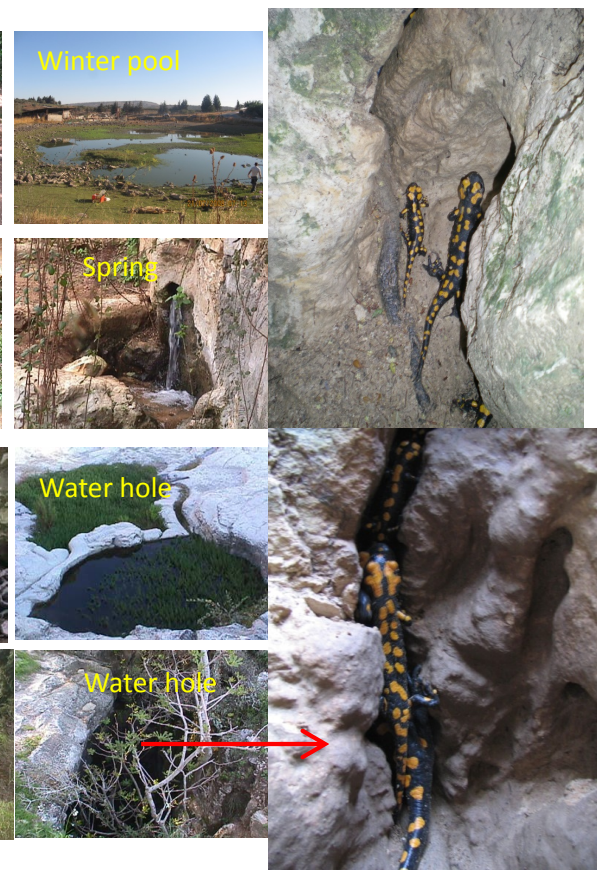

Figure 2. Various breeding places for $S$. infraimmaculata including a picture of captured salamanders trying to exit the water hole but are unable to do so: A. Pond in which water is available for 5 - 10 months. B. Stream in which water flows all year round with constant temperatures $\left(16^{\circ} \mathrm{C}-18^{\circ} \mathrm{C}\right)$ all year round. $\mathrm{C}$. Winter pond in which water is available for 3 - 6 months. D. Winter reservoir in which water is available during all of the winter and part of the summer all year round for 6 to 12 months. E. Spring in which water is available all year round. $\mathrm{H}$. Water rock pool hole in which water is available during the winter and part of the summer all year round for 6 to 12 months. I. Water rock pool hole in which water is available in the winter and part of the summer for 6 to 8 months. J. Water rock pool hole in which water is available during the winter and part of the summer all year round for 6 to 12 months. K. Winter pool in which water is available for 6 to 8 months. L. Water rock pool hole in which water is available all year round for 6 to 12 months. 
both breeding places): one in which salamanders were unable to return to their terrestrial habitat after laying their larvae (a depth of $195 \mathrm{~cm}$ and an area of 5 $\mathrm{m}^{2}$ ) (Figure 2); and the other in which they were able to return to their terrestrial habitat after breeding.

2) Maalot Rock Pool Hole, which was examined monthly over a period of four years (2005-2008). Both larvae and adults were studied. The larvae measurements were examined, as described previously by Goldberg et al. [34]. The adult salamanders were observed in the pit and outside the rock pool (Figure 2). Pictures of each adult dorsal side of the metamorphosed salamanders and measurements (weight and length) were taken [33]. The lengths and weights of adults and larvae were analyzed according to body mass index (BMI), BMI = weight/length, and one-way ANOVA, with the level of significance between groups set at $\mathrm{p}<0.05$. In addition, average lengths and weights were compared using a t-test. Each adult that was captured was photographed, its weight and length were measured [23], and the mean \pm SE of length and weight were calculated.

\section{Results}

S. infraimmaculata distributed in Israel are presented in Figure 1. Two different habitats must exist for $S$. infraimmaculata: aquatic, to enable them to complete the life cycle (see Figure 2); and terrestrial, to adapt to the salamanders' distribution. Among the various types of breeding places, large numbers of springs and streams (503) were detected on the map of northern Israel (Table 1), and a relatively low number in water holes (48) and winter pools (25). All of these breeding sites are in the area of $\mathcal{S}$. infraimmaculata distribution. In all of the breeding site types (springs, streams, water holes, winter pools and reservoirs), the larvae of salamanders were found in previous studies [2] [3] [4] [10] [18] [19] [20] [22] [23] [26] [27] [30]-[41].

In the present study, we found that another breeding site was found for salamanders near the water hole breeding sites (Figure 3), thus enabling them to exit. In this situation, only a few mature salamanders moved to the water hole where salamanders can enter but are unable to exit (Table 2). Both males and females enter the water hole (Figure 3). During the winter, more males (42\%) were observed than females $29 \%$ (Figure 4). After the salamanders' oviposition in the water, they try to return to terrestrial habitats but are unable to do so (Figure 2), and they lose weight (Figure 5) and die. The decrease in body mass

Table 1. Water bodies in the habitats of Salamandra infraimmaculata distribution in Israel (Figure 1).

\begin{tabular}{cc}
\hline Type of Water Body & Number of Water Bodies \\
\hline Springs and streams & 503 \\
Water holes & 48 \\
Winter pools & 25 \\
Winter reservoirs & 7 \\
\hline
\end{tabular}


Table 2. Number of adult salamanders captured in water holes in Israel annually. Based on our detailed observation of two breeding sites, water holes into which salamanders enter but are unable to exit and die combined with the number of water holes, the estimated damage to the population of salamanders in Israel may be calculated.

\begin{tabular}{cc}
\hline Water Holes & Number of Salamanders Annually \\
\hline Water holes & 9 \\
Maalot Rock Pool Hole & 5 \\
Mount Carmel water hole & 6 \\
Estimated potential damage $7 \times 48$ & 336 \\
\hline
\end{tabular}

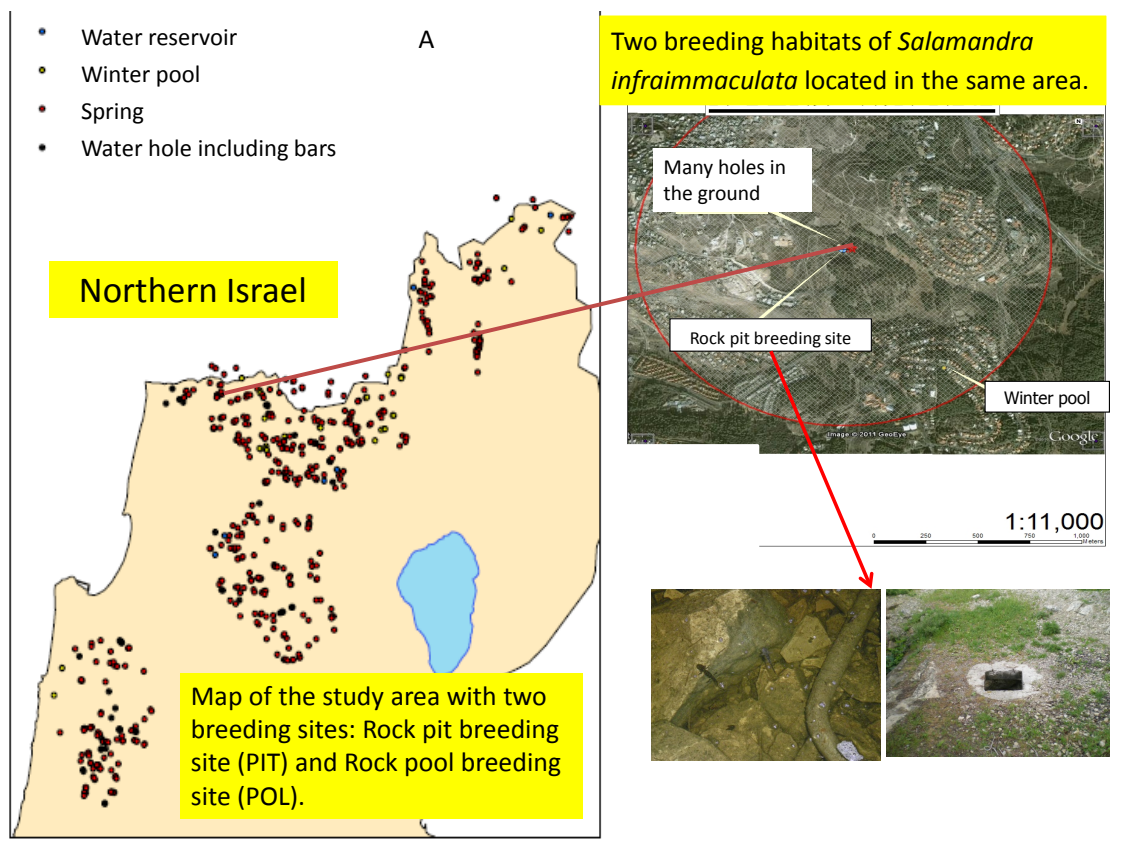

Figure 3. The area around the water hole and the winter pool that were studied.

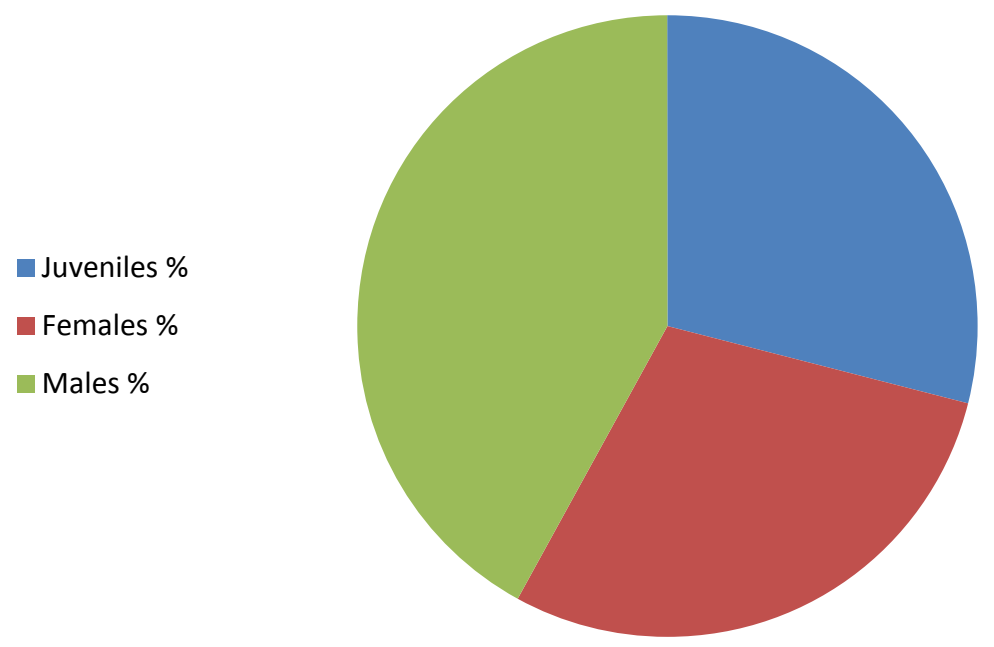

Figure 4. The composition of the metamorphosed $S$. infraimmaculata population (in and out of the two breeding places). The number of salamanders ( $S$. infraimmaculata) in two breeding sizes was $57(27+30)$. 

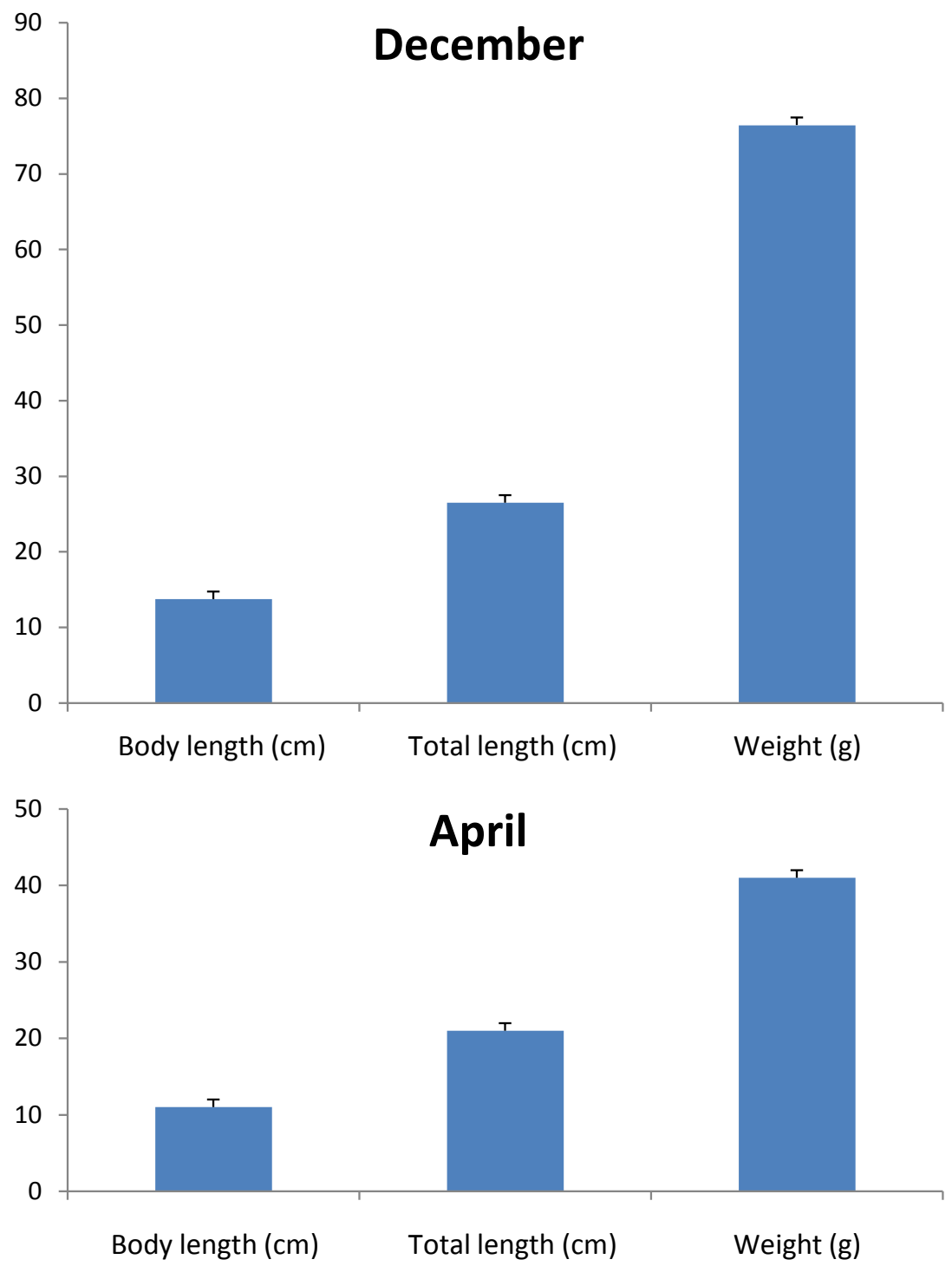

Figure 5. The measurements of mature salamanders in winter (December) after moving to the water hole and in spring (April) when the salamanders are trapped in the pit. Each adult that was captured was photographed, its weight and length were measured [23], and the mean \pm SE of length and weight were calculated.

index (BMI) of salamanders from the winter (December) after they move to the water hole to the spring (April) when they are found in the water hole is shown in Figure 6.

\section{Discussion}

The contribution of this study is that it described in a relatively large area the potential damage to mature $S$. infraimmaculata in xeric habitats where there are limited breeding places and many water holes. Moreover, the distance between breeding places (water pools) in the present study and the water hole was at least $1 \mathrm{~km}$, according the distance that $S$. infraimmaculata move from the location where they deposit their larvae to a terrestrial habitat. Compared to the relatively large 
number of studies carried out on the breeding places of $S$. infraimmaculata on the southern border of its distribution in xeric habitats [2] [3] [4] [10] [18] [19] [20] [22] [23] [26] [27] [30]-[41], only a few studies described water holes as a breeding place that became a death trap for salamanders [32] [33] in the natural area of $S$. infraimmaculata.

The contribution of the present study is that it tried to map breeding sites and divide them into different types (springs and streams, water holes, winter pools and winter reservoirs) whereby water holes represent $8 \%$ of the breeding places. The estimation according to this study and a previous study is that there are 336 adult salamanders annually (Table 1 and Figure 2). Although many water holes have not been examined in detail in the entire area of distribution of $S$. infraimmaculata in Israel, death traps were found where salamanders were captured [32] [33], some of which have not been published. Moreover, some of the new human-made water bodies, for example, swimming pools, are becoming death traps for salamanders [32]. We proposed a model for a death trap that the $S$. infraimmaculata would not be able to recognize during the colonization of new breeding sites (Figure 7). During reproduction, the salamanders move to

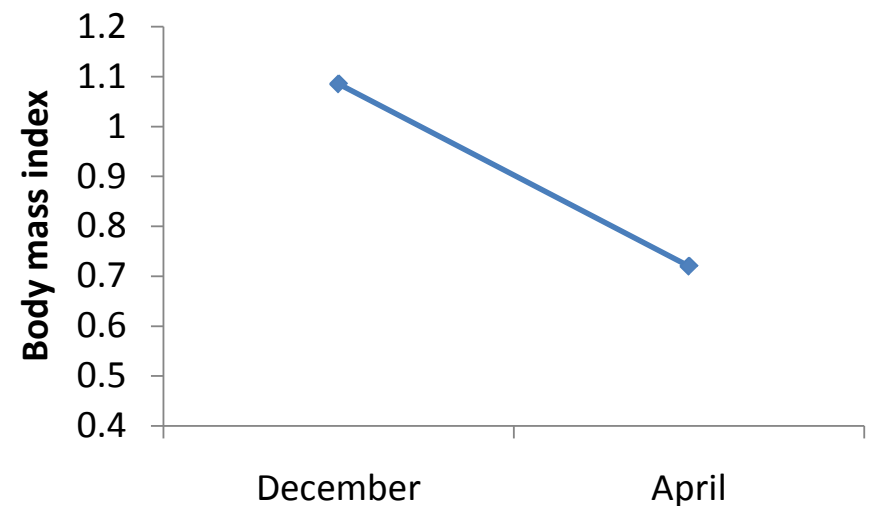

Figure 6. The body mass index (BMI) of salamanders in winter (December) after moving to the water hole and in spring (April) when the salamanders are trapped in the pit.

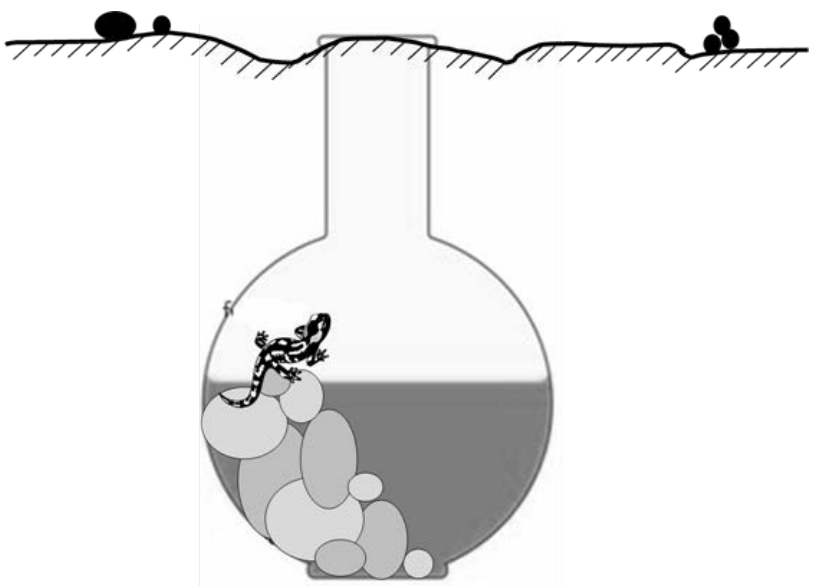

Figure 7. The quality model proposing the death trap in semi-arid habitats based on our studies (present study [32] [33]). 
the breeding sites. This migration in most of the semi-arid habitats is relatively high [4] [23] [30] [31] compared to moist habitats, where many streams for breeding are found [28]. In Mount Carmel, semi-arid areas of the southern population in Israel and the long distance of moving to and between breeding sites are described [27]. This study supports the hypothesis proposed by Degani et al. [33] that in salamanders, colonization is an important aspect of adaptation to semi-arid habitats, where many breeding sites are unpredictable. Some breeding sites dry up during the summer and even do not contain water in very dry years. Some human-made breeding sites become death traps and damage natural populations, particularly in semi-arid habitats where the populations are very rare. Considerably more studies must be carried out in all areas of $S$. infraimmaculata distribution under Mediterranean semi-arid conditions to describe this damage.

\section{Acknowledgements}

We would like to thank the Tel-Hai Map Archive for providing me with the cartographic assistance, and Dr. Alon Margalit and Dr. Salome Transkei for their help.

\section{Conflicts of Interest}

The authors declare no conflicts of interest regarding the publication of this paper.

\section{References}

[1] Steinfartz, S., Veith, M. and Tautz, D. (2000) Mitochondrial Sequence Analysis of Salamandra taxa Suggests Old Splits of Major Lineages and Postglacial Recolonizations of Central Europe from Distinct Source Populations of Salamandra salamandra. Molecular Ecology, 9, 397-410. https://doi.org/10.1046/j.1365-294x.2000.00870.x

[2] Degani, G. (1996) The Salamander at the Southern Limit of its Distribution. Laser Pages Publ. Ltd., Jerusalem.

[3] Degani, G. (2017) Ecological, Biological, Behavioral and Genetic Adaptation to Xeric Habitats of Triturus vittatus vittatus (Urodela) on the Southern Border of its Distribution. Journal of Marine Science: Research and Development, 7, 1-13. https://doi.org/10.4172/2155-9910.1000226

[4] Degani, G. (2017) Ecological, Biological and Genetic Adaptation to Xeric Habitats of Salamandra infraimmaculata on the Southern Border of its Distribution. Open Journal of Animal Sciences, 7, 70-92. https://doi.org/10.4236/ojas.2017.71007

[5] Merabet, K., Sanchez, E., Sanchez, A., S., B., Bogaerts, D., Steinfartz, S., Joger, U., Vences, M., Karar, M. and Moali, A. (2016) Phylogeographic Relationships and Shallow Mitochondrial Divergence of Algerian Populations of Salamandra algira. Amphibia-Reptilia, 10, 1-10. https://doi.org/10.1163/15685381-00003025

[6] Blank, L., Sinai, I., Bar-David, S., Peleg, N., Segev, O., Sadeh, A.N., Kopelman, N.M., Templeton, A.R., Merilä, J. and Blaustein, L. (2013) Genetic Population Structure of the Endangered Fire Salamander (Salamandra infraimmaculata) at the Southernmost Extreme its Distribution. Animal Conservation, 16, 412-421.

https://doi.org/10.1111/acv.12009 
[7] Czypionka, T., Goedbloed, D.J., Steinfartz, S. and Nolte, A.W. (2018) Plasticity and Evolutionary Divergence in Gene Expression Associated with Alternative Habitat Use in Larvae of the European Fire Salamander. Molecular Ecology, 27, 2698-2713. https://doi.org/10.1111/mec.14713

[8] Degani, G., Goldberg, T. and Nevo, E. (2014) Genetic Variation in Salamandra infraimmaculata from Different Habitats Using Amplified Fragment Length Olymorphism. Journal of Biophysical Chemistry, 5, 54-66. https://doi.org/10.4236/jbpc.2014.52007

[9] Degani, G., Jackson, K., Dosoretz, C. and Plotzky, Y. (1999) Molecular DNA Variation in Salamandra infraimmaculata from Different Habitats. Israel Journal of Zoology, 44, 239-246.

[10] Degani, G. and Kaplan, D. (1999) Distribution of Amphibian Larvae in Israeli Habitats with Changeable Water Availability. Hydrobiologia, 405, 49-56.

https://doi.org/10.1023/A:1003796820900

[11] Goedbloed, D.J., Czypionka, T., Altmüller, J., Rodriguez, A., Küpfer, E., Segev, O., Blaustein, L., Templeton, A.R., Nolte, A.W. and Steinfartz, S. (2017) Parallel Habitat Acclimatization Is Realized by the Expression of Different Genes in Two Closely Related Salamander Species (Genus Salamandra). Heredity, 119, 429-437.

[12] Goldberg, T., Nevo, E. and Degani, G. (2010) Genetic Variation in Salamandra infraimmaculata from Various Breeding Sites-A Model for Habitat Selection. Asian Herpetological Research, 1, 1-9.

[13] Goldberg, T., Nevo, E. and Degani, G. (2011) Genetic Diverseness and Different Ecological Conditions in Salamandra infraimmaculata Larvae from Various Breeding Sites. Animal Biology Journal, 2, 37-49.

[14] Goldberg, T., Pearlson, O., Nevo, E. and Degani, G. (2007) Mitochondrial DNA Analysis of Salamandra infraimmaculata Larvae from Habitats in Northern Israel. Progrese şi Perspective in Medicina Veterinară, Lucrări ştiințifice, 23-31.

[15] Goldberg, T., Pearlson, O., Nevo, E. and Degani, G. (2009) Sequence Analysis of Mitochondrial DNA in Salamandra infraimmaculata Larvae from Populations in Northern Israel. South American Journal of Herpetology, 4, 268-274. https://doi.org/10.2994/057.004.0310

[16] Veith, M., Degani, G. and Seitz, A. (1992) High Genetic Homogeneity of Salamandra salamandra (L.) in Israel. Zoologischer Anzeiger, 229, 63-72.

[17] Veith, M., Degani, G. and Seitz, A. (1992) Discordance of Genetical and Morphological Variation of Salamandra salamandra (L) in Israel. Zoologischer Anzeiger, 229, 63-72.

[18] Degani, G. (1982) Amphibian Tadpole Interaction in a Winter Pond. Hydrobiologia, 96, 3-8. https://doi.org/10.1007/BF00006274

[19] Degani, G. (1986) Growth and Behavior of Six Species of Amphibian Larvae in a Winter Pond in Israel. Hydrobiologia, 140, 5-10. https://doi.org/10.1007/BF00006723

[20] Degani, G. (1993) Cannibalism among Salamandra salamandra (L.) Larvae. Israel Journal of Zoology, 39, 125-129.

[21] Degani, G. (2016) Cannibalism, among Other Solutions of Adaption in Habitats Where Food Is Not Available for Salamandra infraimmaculata Larvae Diet in Breeding Places in Xeric Habitats. Open Journal of Animal Sciences, 6, 31-41. https://doi.org/10.4236/ojas.2016.61005

[22] Blank, L. and Blaustein, L. (2014) A Multi-Scale Analysis of Breeding Site Characte- 
ristics of the Endangered Fire Salamander (Salamandra infraimmaculata) at its Extreme Southern Range Limit. Hydrobiologia, 726, 229-244.

[23] Degani, G. and Mendelssohn, H. (1978) The Food of Salamandra salamandra (L.) Tadpoles in Israel in Different Habitats. The Israel Journal of Ecology C, 19-45.

[24] Degani, G. and Mendelssohn, H. (1981) Interaction of Amphibian Larvae in a Winter Rain Pond. Israel Journal of Zoology, 30, 99-100.

[25] Degani, G. and Mendelssohn, H. (1981) Moisture as a Factor Influencing Selection of Hiding Places by Juvenile Salamandra-salamandra from Semi-Arid Habitats. In: Shuval, H.I., Ed., International Meeting of the 12th Scientific Meeting of the Israel Ecological Society, Balaban International Science Services, Philadelphia, Jerusalem, 49-56.

[26] Goldberg, T., Nevo, E. and Degani, G. (2009) Breeding Site Selection According to Suitability for Amphibian Larval Growth under Various Ecological Conditions in the Semi-Arid Zone of Northern Israel. Ecologia Mediterranea, 35, 65-74.

[27] Bar-David, S., Segev, O., Peleg, N., Hill, N., Templeton, A.R., Schultz, C.B. and Blaustein, L. (2007) Long-Distance Movements by Fire Salamanders (Salamandra infraimmaculata) and Implications for Habitat Fragmentation. Israel Journal of Ecology and Evolution, 53, 143-159. https://doi.org/10.1080/15659801.2007.10639579

[28] Degani, G. and Mendelssohn, H. (1982) Seasonal Activity of Salamandra salamandra (L.) (Amphibia, Urodela) in Headwaters of the Jordan River. Israel Journal of Zoology, 31, 77-85.

[29] Degani, G. and Warburg, M.R. (1978) Population Structure and Seasonal Activity of the Adult Salamandra salamandra (L.) (Amphibia Urodela Salamandridae) in Israel. Journal of Herpetology, 12, 437-444. https://doi.org/10.2307/1563347

[30] Warburg, M.R. (1993) Long-Term Studies on Population Structure and Reproductive Strategies in a Salamandra salamandra Population on Mt. Carmel. Israel Journal of Zoology, 39, 77.

[31] Warburg, M.R. (1994) Population Ecology, Breeding Activity, Longevity, and Reproductive Strategies of Salamandra salamandra during an 18-Year Long Study of an Isolated Population on Mt. Carmel, Israel. Mertensiella, 4, 399-421.

[32] Degani, G. and Goldberg, T. (2015) Effect of Human Activity in Creating a Death Trap for Salamandra infraimmaculata Seeking Breeding Places during Colonization of New Breeding Sites. American Open Animal Science Journal, 2, 1-11.

[33] Degani, G., Sela, E., Henkin, Z., Korem, S., Goldberg, T. and Warburg, M.R. (2007) Movement to Rock Pool Hole Breeding Sites of Salamandra infraimmaculata during Colonization of New Breeding Places in Xeric Habitats. Salamandra, 43, 7-12.

[34] Goldberg, T., Nevo, E. and Degani, G. (2012) Amphibian Larval in Various Water Bodies in the Semi-Arid Zone. Zoological Studies, 51, 345-361.

[35] Degani, G. and Warburg, M. (1995) Variation in Brood Size and Birth Rates of Salamandra salamandra (L.) (Amphibia, Urodela) from Different Habitats in Northern Israel. Amphibia-Reptilia, 16, 341-349. https://doi.org/10.1163/156853895X00424

[36] Degani, G. and Warburg, M.R. (1976) Biological and Ecological Studies on the Salamandra salamandra. Israel Journal of Zoology, 25, 206-207.

[37] Segev, O. and Blaustein, L. (2007) Priority Effects of the Early Breeding Fire Salamander on the Late Breeding Banded Newt. Hydrobiologia, 583, 275-283.

https://doi.org/10.1007/s10750-006-0565-6 
[38] Segev, O. and Blaustein, L. (2014) Influence of Water Velocity and Predation Risk on Fire Salamander (Salamandra infraimmaculata) Larval Drift between Temporary Pools in Ephemeral Streams. Freshwater Science, 33, 950-957.

https://doi.org/10.1086/676634

[39] Warburg, M. (1992) Breeding Patterns in Fringe Population of Fire Salamanders, Salamandra salamandra. Journal of Herpetology, 2, 54-58.

[40] Warburg, M. (2007) Longevity in Salamandra infraimmaculata from Israel with a Partial Review of Life Expectancy in Urodeles. Salamandra, 43, 21-34.

[41] Warburg, M.R., Degani, G. and Warburg, I. (1979) Growth and Population Structure of Salamandra-Salamandra Larvae in Different Limnological Conditions. Hydrobiologia, 64, 147-156. https://doi.org/10.1007/BF00023190 